\title{
The Gods must be Crazy, or the rhetoric of apartheid: a (re)evaluation of Jamie Uys's movie in the context of French anti- apartheid solidarity
}

\author{
Namara Burki \\ Sciences Po Paris, France \\ namara.burki@sciencespo.fr
}

\section{ABSTRACT}

Jamie Uys's 1980 film The Gods must be Crazy was an instant blockbuster as it opened up in theatres world-wide. However, critics were quick to note that its humorous tone subtly propagated the central tenet of apartheid, namely separate development. This paper analyses its specific reception in France and replaces it within the context of growing antiapartheid solidarity and rhetoric. Although journals such as Politique Africaine were quick to denounce its racist undertones and implicit support of apartheid policies, condemnation remained limited to militant circles, which in turn questions the ways in which French society perceived the situation in South Africa. Drawing on the works of Keyan Tomaselli and Brendon Nicholls, this paper offers a critical analysis of the movie in the context of apartheid ideologies and growing anti-apartheid rhetoric by: (1) looking at the state of the mobilization and the specific context of cultural anti-apartheid manifestations in France prior to the opening of the movie on French screens in 1981, before (2) analysing how its positive reception inserted itself within a broader framework of European colonial discourse and thus effectively served as a tool of apartheid propaganda.

Keywords: The Gods must be Crazy; Jamie Uys; France; apartheid; anti-apartheid; propaganda; culture; protest 


\section{Introduction}

In 1981, the "slapstick comedy" The Gods must be Crazy opened up in theatres world-wide and was met with resounding success. The tale of a San man of the Kalahari Desert - propelled into the whirls of modern-day society when a Coca-Cola bottle falls from the sky and disrupts the Edenic peace of his people - quickly gripped the hearts of Western audiences. At the time, the South African director Jamie Uys had made a name for himself with twenty-two movies that celebrated in one way or another Afrikaner culture. Though The Gods must be Crazy was listed as Botswana-made, it was financed by South African capital, a strategy used to effectively counter the cultural boycott that was imposed on the Pretoria regime. Indeed, the 1980s in South Africa were marked by the uprisings led by the by the United Democratic Front (UDF) and the Congress of South African Trade Unions (COSATU), and the mass scale repression demonstrated by the apartheid regime eventually sparked international outrage. Comparable in its scope to the anti-slavery campaign and the global anti-colonial struggle, anti-apartheid solidarity soon took on a transnational nature, drawing together organizations in more than 100 countries (Thörn, 2006). As a result, increasing emphasis was put on cultural and symbolic action to denounce the system of apartheid and demand the respect of the sanctions on the country called upon by the United Nations since the 1960s. This tumulus context serves as a fundamental backdrop to our analysis of the specific reception of the movie The Gods must be Crazy in France, and the conclusions we can draw from it with regards to growing anti-apartheid solidarity and rhetoric. Although certain critics were quick to note that the humorous tone of the movie subtly propagated the central tenet of apartheid - namely, separate development the film remained one of the highest grossing South African movies produced during the apartheid period and constituted one of the main successes of the South African propaganda machinery.

Though protests were organized in New York to denounce the movies thinly veiled racism, condemnation of the movie in France only came through the form of publications by militant journals. In fact, it received a rather positive reception in the French media and benefited from a strong audience presence at the opening of its sequel The Gods must be Crazy II in 1989. This paper argues that the positive reception of French audiences and the rather limited response by French anti-apartheid structures was linked to one of the failings of the French solidarity movement: ideological divisions that relegated the anti-apartheid cause to the whims of French political party apparatus. Indeed, the main French anti-apartheid solidarity structures from the 1970s to the 1990s - namely, the Association Française d'Amitié et de Solidarite avec les 
Peuples d'Afrique (AFASPA, 1972) and the Mouvement Anti-Apartheid (MAA, 1974) - were divided along allegiances to the Communist party (PCF) on the one hand, and the Socialist party (PS) on the other. In the context of the Cold War, this schism between socialists and communists ultimately led to the anti-apartheid struggle serving as a battleground for the ideological and political justifications of a French Left in crisis, weakening in that sense the scope of their actions.

Consequently, this study analyses the circulation of a particular cultural product and the ideological and political repercussions it had on the French anti-apartheid solidarity movement. At the heart of this endeavour is the different perceptions of the protagonists of this movement, both in France and in South Africa: as a result, our work relied heavily on the use of oral history through in-depth interviews conducted with both French and South African militants. Drawing on the works of Keyan Tomaselli and Brendon Nicholls, this paper offers a critical analysis of the movie in the context of apartheid ideologies and growing anti-apartheid rhetoric, by: (1) looking at the state of the mobilization and the specific context of cultural anti-apartheid manifestations in France prior to the opening of the movie on French screens in 1981, before (2) analysing how its positive reception inserted itself within a broader framework of European colonial discourse and thus effectively served as a tool of apartheid propaganda. In that sense, the notion of celebrity - of South African artists, as well as the movie's popularity - is critically assessed in as much as it succeeded or failed to raise awareness on the apartheid question abroad.

\section{Culture as protest}

\section{The French anti-apartheid movement: a movement divided along ideological lines}

In March 1960, as a response to the traumatic events of Sharpeville (21 ${ }^{\text {st }}$ of March 1960) where 69 protestors lost their lives, the Comité pour la justice et l'égalité en Afrique du Sud was formed under the impetus of Alioune Diop, the Senegalese intellectual and founder of the revue Présence Africaine (1947). Composed of various student organizations of immigrant backgrounds, ${ }^{1}$ the committee received messages of support from personalities such as Josephine Baker, Léopold Sedar Senghor, and Philibert Tsiranana (Konieczna 2017, 127).

\footnotetext{
${ }^{1}$ Including the Fédération des Étudiants d'Afrique Noire en France (FEANF), the Association Générale des Étudiants Martiniquais (AGEM), the Association Générale des Étudiants Guadeloupéens (AGEG), the Association des Étudiants Guyanais, and the Association des Étudiants d'origine Malgache (AEOM).
} 
Although the committee was an ephemeral endeavour and dissolved after its first meeting, it nonetheless highlighted an initial attempt to raise awareness on the South African question, and illustrated how anti-apartheid sentiment in France, at least in its initial stage, stemmed from anti-colonial and Panafrican thought. According to Anna Konieczna, mobilization through semi-permanent and circumstantial committees was characteristic of the specific cultural and political context of post-war France, in which committees frequently constituted a platform of expression and coordination for anti-fascist and anti-colonial milieus (Konieczna 2017, 126). It was only in the early-to-mid 1970s that more permanent anti-apartheid structures such as the Association Française d'Amitié et de Solidarité avec les Peuples d'Afrique (AFASPA) or the Mouvement Anti-Apartheid (MAA) emerged; yet, they remained strongly entrenched in the French party apparatus which ultimately limited their scope of action.

The French anti-apartheid solidarity movement emerged as a reaction to the disavowed collaboration between the French and South African governments - instigated soon after World War II under the impetus of the conservative President Charles de Gaulle - that came to mark the apartheid era. Indeed, following the departure of South Africa from the Commonwealth in 1960, the Pretoria regime actively sought out new diplomatic and economic relations with other European powers, particularly France. An informal relationship was thus established between the two countries, in which South African strategic minerals - particularly gold and uranium were exchanged for French military and nuclear technology. As a response, in 1972, the AFASPA was created as an outsource of the French Communist party (PCF), and regrouped anticolonialist and communist militants who were particularly supportive of the struggles of the African National Congress (ANC) and of the South West African People's Organisation (SWAPO). Yet, another French anti-apartheid solidarity organization, known as the MAA, arose that same year following the mobilization of the Comite Anti-Outspan (CAO) in 1974 for the boycott of Outspan oranges. Closer to the milieus of the Socialist party (PS), the MAA recognized the plurality of struggles in South Africa and as such also supported the liberation movement of the Pan-Africanist Congress (PAC) and, to a lesser extent, the Black Consciousness Movement (BCM). However, given the context of the Cold War and the growing anti-communist rhetoric associated with it, deep ideological tensions existed between the two French movements, leading them to organize separate campaigns. As Jacqueline Dérens, a prominent French militant and member of the AFASPA, recalls: "In France, at that time, the Left defined itself around two close enemies, the Socialist Party and the Communist 
Party; once you were in one camp, you had to stay there [own translation] 2"(Dérens 2006, 31). Consequently, this on-going friction weakened the strength and outreach of the mobilization and presented a divided front in the French support for the anti-apartheid struggle. Nevertheless, as mounting social and political contestation was raging in South Africa, strong manifestations of cultural boycotts and protests were taking place on the international scene and served to bolster anti-apartheid rhetoric.

\section{The role of artists in the anti-apartheid movement: bridging the ideological} gap?

On the $5^{\text {th }}$ of December 1979, at the Théâtre de l'Essaïon in the $4^{\text {th }}$ arrondissement of Paris, the theatre group Les Quatre Chemins opened up the evening with a production of the South African play L'île prison, originally known as The Island. Written in 1973 by the South African artists Athol Fugard, John Kani, and Winston Ntshona, The Island was created as a tribute to the South African freedom fighters and served to denounce what was seen as a "conspiracy of silence": the idea that people had been lulled by the everyday repression of the apartheid regime (John Kani, Johannesburg, 16.01.2018). Art, and theatre, thus became a way to channel the ideals of liberation and transposed the apartheid question unto the international scene. Indeed, at the time, the solidarity movement was effectively congregating around South Africans in exile, particularly around artists. In 1973, the famed English director Peter Brook - who was then working at the theatre of the Bouffes du Nord, in Paris - took his crew to London to see The Island. As John Kani recalls:

In 1973, we were performing The Island in the West End, and Peter Brook brought the entire theatre company from Paris. And Peter Brook said: "We've been doing method, we've been doing avant-guard, we've been doing convention, I'm taking you to London to see two men on the stage, who use the space with their voices, with their bodies and hide the painful truth within their performance, but it is louder than the fact that it is hidden." (John Kani, Johannesburg, 16.01.18)

The international renown of the production and of its cast carried on six years later, when the French adaptation L'île prison opened up at the Théâtre de l'Essaïon under the direction of Catherine de Seynes and her company Les Quatre Chemins. Each representation was accompanied by a brochure with a description of the play and the biography of the

\footnotetext{
${ }^{2}$ For the sake of this study, source material in French has been translated by the author.
} 
screenwriters, as well as information - provided by the MAA - on the situation in South Africa and its on-going liberation struggle. Two years earlier, the theatre company had produced the show Sud Afrika ${ }^{3}$ in Saint Nazaire, which they animated in schools with an exhibition of photographs presenting different facets of the apartheid system. In a 1979 memorandum, Catherine de Seynes recalls the general lack of awareness on the topic:

Most of the children (13 to 17 years old) and their teachers knew nothing, or almost nothing of what was going on there - "it's too far." Some teachers showed us the only information they had: magnificent brochures, illustrated with attractive pictures sent by the South African embassy and the Ministry of Education [own translation]. (De Seynes, 1979)

Although the South African embassy actively partook in a propaganda campaign to dispel some of the information seeping out of the country, cultural manifestations and theatre became a way to actively denounce the apartheid system and reached branches of the French population that were not necessarily receptive to traditional militant tactics such as protests and demonstrations. Moreover, The Island's artistic cast met with anti-apartheid and solidarity structures through their tours abroad, and thus became ambassadors of the anti-apartheid cause. However, John Kani recalls the particularly inhospitable feeling most black South African felt the first time they arrived in France, eventually leading them to move to countries like Germany and Holland that were seemingly more welcoming:

Every time we went to Paris we met these structures: we met the people of antiapartheid, we met artists. [...] What I found very amazing was that people in France talked about discrimination. I thought: "Hey hey, you're a free country, you're a model of democracy, what are you talking about?" Many South African artists, people like Gerard Sekoto, in their books, in their stories - we met in London - talk about how difficult life is in Paris or in France for black African immigrants: the inhospitable reception of refusing even to help you communicate, by simply refusing to speak any other language except French. That was the first experience of black exiles in France, [they were] not welcome. (John Kani, Johannesburg, 16.01.18)

Nevertheless, France was seen as the "heart of culture" and in that sense remained attractive to South Africans artists. Yet, interest in their work was marred by a focus on its "exotic" nature:

\footnotetext{
${ }^{3}$ The play was created by Anne Barbey in 1971 in Lausanne, Switzerland.
} 
People just wanted... they were more interested, in France, in your work as an artist, more than being a political exile. And, they wanted to look at this new art form that comes from Africa, and you could see that influence in what French art is today. You could see that African influence. So, France became a very strange phenomenon: they like our work, like our culture, but don't like us. (John Kani, Johannesburg, 16.01.18)

Furthermore, there seemed to be a difference in favour with regards to black and white South African exiles: those who were white were more easily assimilated into French culture - as is exemplified by the experience of the South African poet and painter Breyten Breytenbach - and were effectively given a voice, becoming the representatives of South Africans in exile:

And then there would be rallies and the French South Africans would speak, and they assimilated into the French culture, and it gave them the comfort of being there. And yet, people like Gerard Sekoto, people like the artists who went there still remained in a limbo: they're not refugees, they still remain exiles. (John Kani, Johannesburg, 16.01.18)

As a result, black South Africans in exile - compared to their white counterparts - were talked about and used as references, instead of being actively included in the structures of solidarity and support for the South African liberation struggle. This, however, wasn't solely a French issue and concerned the transnational anti-apartheid movement as a whole. Indeed, one of the tensions that plagued the movement, at its inception in Britain but also throughout the period of transnational solidarity, was the question of race and representation. As Christabel Gurney, an Anti-Apartheid Movement (AAM) activist, notes: the anti-apartheid struggle "had the vision to see that, if it was to grow, the Movement must put down British roots" (Gurney 2000, 137), which in other words meant that "international solidarity in Britain at the time would come easier if the persons appealing for it had a white face - and spoke with a British accent" (Thörn 2006, 74).

Nevertheless, cultural manifestations played an important role by providing new platforms of expression to condemn apartheid, and in that respect differentiated themselves from traditional anti-apartheid mobilization around the French political party apparatus. In December 1981, the association Artistes du Monde contre l'Apartheid was formed ${ }^{4}$ and launched a campaign calling for the active involvement of intellectuals and artists across the globe in publicly affirming their

\footnotetext{
${ }^{4}$ This initiative was notably supported by the UN's Special Committee Against Apartheid.
} 
support for the ideals of "liberty and human dignity" (AFASPA 1940-1995). Ninety-five artists answered the call - including Roy Lichtenstein and Pierre Soulages - and donated one of their works to illustrate their support for the struggle. Following this first initiative, the Fondation Culturelle contre l'Apartheid was formed in November 1983, and counted amongst its board members prominent intellectuals such as Jacques Derrida, Susan Sontag, and Olaf Palme, illustrating once again the symbolic engagement of intellectuals for the cause. Finally, in 1985, Artists Against Apartheid (AAA) was launched in Britain and effectively consolidated the cultural boycott movement. Nonetheless, these cultural manifestations also came at a time of increasing propaganda by the Pretoria regime that was actively attempting to present a gilded image of South Africa to the international community. This strategy was notably bolstered by the opening of the movie The Gods must be Crazy, whose positive reception in France evinced the perpetuation of racist tropes within French society.

\section{The rhetoric of apartheid}

\section{From ethnographic museums to movie screens: a colonial representation of the Khoisan}

In 1975, the South African embassy in Paris acquired the services of the Centre d'Études et de Diffusion du Film (CEDFI) - an independent cinematheque founded in 1960 - that organized free screenings of South African tourist and propaganda movies (MAA, 1975). This highlighted the ways in which the Pretoria regime was actively attempting to improve its image in the eyes of the international community, particularly through the medium of culture. Yet, its real cultural breakthrough came with the movie The Gods must be Crazy, produced in 1980 by the South African filmmaker Jamie Uys. An instant blockbuster, the movie opened up in theatres in over 15 different countries, was awarded in France with the Grand Prize of the Chamrousse Festival dedicated to film comedies in 1982, and was nominated for a César in the Best Foreign Film category in 1984. However, critics were quick to note that the humorous tone of the movie subtly propagated the central tenet of apartheid, namely separate development. According to Horst Kleinschmidt - an anti-apartheid activist and director of the International Defence and Aid Fund (IDAF) in the 1980s - Jamie Uys thrived on white people's perceptions, and as a result "it was easy for white people to watch it, without being really challenged" (Horst Kleinschmidt, Cape Town, 01.02.18). As Keyan Tomaselli notes, the career of Jamie Uys was marked by subtle racism, and directly benefited from the celebration of Afrikaner culture: 
The Jamie Uys Films company was used by Afrikaner intellectuals and capital to affirm cultural perspectives of the emerging Afrikaner petit bourgeoisie of the 1960s and 1970s. The ethnic and political discourses of Uys's later films (1974-1989), made under the auspices of the Mimosa Company, not only framed apartheid mythology, but concealed and deflected actual conditions which contradicted Uys's films and statements about people, places, events and processes. (Tomaselli 2006, 174)

Throughout Jamie Uys's films, Keyan Tomaselli identified three narrative themes that punctuated our understanding of the movie: (1) the hostile desert, relationships and technology; (2) "Disneyfying" animals and people; and (3) white myths about people, places and animals (Tomaselli 2006, 175-178). The first theme is presented in The Gods must be Crazy through the expansive filming of the Kalahari Desert on the one hand - conveying the idea of an Edenic environment, untouched by the ills of modern-day society - and, on the other, the overindustrialized and chaotic context of the big city. This contrast subsequently serves to highlight the fundamental difference between the experiences of the black and the white man and, as a result, reproduces the colonial frontier between an "us" and a "them". The second theme "focuses attention on Bushmen in a zoological way" (Tomaselli 2006, 177), associating them with the animal world. This is particularly illustrated in the scene where $\mathrm{Xi}$ - the "Bushman" portrayed by the San actor N!xau - "talks" to a baboon. However, Tomaselli nuances this analysis by noting that a racist interpretation of the scene rests "in the eye of the viewer": by recalling an interview he conducted with an anti-apartheid militant in Soweto, the latter claimed, "You whites, I see you talking all the time to your dogs. Does that reduce you to the level of your dog?" (Tomaselli 2006, 177). Although this statement highlights a possible biased focus by adamant critics of the movie, one can still assert that the scene nonetheless drew on the greater tropes of dehumanizing and animalizing black bodies and would have thus been interpreted in such a way by the majority of Western audiences. Finally, the last theme of the movie is summarized as an overarching presupposition of white superiority, with the character of Xi portrayed as the quintessential innocent "Bushman", leading to the de-historicization and mocking of the legacy of the indigenous people of South Africa, namely the Khoi and the Khoisan.

These narratives directly stem from centuries' old racist and colonial representations of the Khoisan and found a particular echo, through the guise of humour, in French society. Indeed, since Hans Burgkmai's $16^{\text {th }}$ century engraving In Allago, the Khoisan have come to occupy a 
preponderant space in Western perceptions of the African continent and served as a basis for the construction of a colonial gaze on the people that populate it. In that sense, the engraving presented an idealized image of the population of the South African coast and contributed to cementing them in a specific time and space. With the universal exhibitions that started in Europe in 1851, a sampled microcosm was presented as a macrocosm, where transposed objects and peoples became constitutive of a radical alterity and were displayed in "pilgrimage sites of a commodity fetishism" (Corbey 1993, 340). The universal exhibition of 1878 in Paris was the first to showcase people from non-Western cultures in indigenous villages, built to accentuate the fundamental difference between an "us" and a "them". In that sense, the Khoisan came to represent "living relics of prehistory [own translation]" (Fauvelle 2007, 27), while their objectification and exploitation also came through the form of the overt sexualisation of the black woman's body. Sharpley-Whiting (1999) delves into the complex construction of what she terms the "Black Venus master narrative" in which black women - ranging from $19^{\text {th }}$ and $20^{\text {th }}$ century French representations of the infamous Hottentot Venus to cultural figures such as Josephine Baker - came to represent "ultimate difference (the sexualized savage) and inspire repulsion, attraction, and anxiety, which gave rise to the collective French male imaginations of Black Venus (primitive narratives)" (Sharpley-Whiting 1999, 6).

In that sense, the oscillation between idealized and savage depictions of indigenous people of Southern Africa found an echo in the romanticized depiction of the San people in The Gods must be Crazy. By providing a platform for the showcasing of a San man, N!xau, as a caricature on the international scene, having him wear the same clothes as his character on the opening nights of the movie screening, the movie effectively portrayed the actor and his people as the quintessential emanation of the "indigenous man". In that respect, the movie cemented the image of a "stone-age people frozen in a technologically innocent Eden, still practicing their environmentally attuned hunter-gatherer lifestyle in happy isolated splendour" (Bregin 2001, 91). As a result, the "Bushman" people were presented as the exemplification of "the subhuman other of Western alterity discourse":

The Bushmen today are constructed in the same discourse of primordiality they always were; a people out of time and out of history, stone-age remnants living in a state of pristine primitiveness, locked in a cultural inertia that admits no outside influence and precludes their survival in the modern world. (Bregin 2001, 88)

The movie's popularity thus effectively continued the process of "othering" of the Khoisan people by denying them their place and identity in South African society in order to have them 
comply with a desired narrative. Since the 1990s, the few remaining "Bushman" groups have become the source of "extraordinary international focus" and have become "the most highly scientifically (and commercially) commodified 'disappearing' group" (Bregin 2001, 89), leading to their exploitation and exoticization for television and film audiences (Tomaselli 1992, 209). As a result, movies such as The Gods must be Crazy directly reproduced these strategies of commodification and exoticization, relegating the San people to the margins of society, and hence serving as a justification for apartheid policies.

\section{The Gods must be Crazy: a tool of South African cultural propaganda}

By contributing to uphold the ethnographic myths of the "Bushman", the film was complicit with apartheid institutions, which in turn legitimized Uys's exploitation of his San actors. Indeed, according to Brendon Nicholls, the institutionalized perceptions conveyed by the movie were ultimately detrimental to San interests, by presenting them as the quintessential and exotic "other". Moreover, the movie failed to illustrate the complexity of South African reality, and notably the dire social and economic plights of the San people in the Homelands. According to Elizabeth Marshall Thomas, though most of the filming of the movie was done in Tsumkwe, in Namibia, the cameras were careful to avoid "the strewn trash, the mangy dogs, the junk, the barbed wire and the administrative buildings that characterize the town" (Thomas 1988, 245) in order to maintain the mirage of an idealized population, living in harmony with nature. In addition, due to the documentary style of the movie's opening scene, with the use of the ethnographic narrator (whose voice only appears when explaining the action of the San characters), the San people were effectively portrayed as "apolitical, ahistorical and affluent because of their dispossession" (Nicholls 2008, 22). As a result, not only did the movie perpetuate racist and colonial tropes, it was also directly associated with the endeavour of the South African regime to convey a certain idea on the country and its people. According to Zenzile Khoisan, a freelance journalist and an anti-apartheid activist:

That film was sponsored by a racist regime which wanted to depict a certain image of South Africa. And Jamie Uys was on that regime's payroll, I know this very well. And that film was part of the South African cultural brigade, it was part of its arsenal. (Tomaselli 2006: 180-181)

As such, the film must be understood "in terms of what it represents in its historical context" (Tomaselli 2006, 180-181), and gives the unsettling idea that "Apartheid had a sense of humour" (Nicholls 2008, 21). As Peter Davis has suggested, Uys's slapstick comedy worked 
to dissipate international political anger, by providing the international audience with a humorous window into the country: "The Gods must be Crazy was one of the best antidotes to the poisonous name that apartheid had gained throughout the world, laughing it into nonexistence" (Davis 1996, 94). Indeed, critics only recalled the burlesque aspect of the movie, and its racist premises were relegated to "this undefined fringe of 'harmless' racism [own translation]" (Davis 1986, 53). The disruptive power of humour thus served to dispel mounting criticism of the apartheid system, and as a result situated the movie within a broader tradition of upholding racial ideologies. ${ }^{5}$

Nevertheless, as a result of these degrading representations and the thinly-veiled racist premises of the movie, a silent boycott was instigated by black audiences in South Africa. Protests were organized at movie screenings in New York, and French journals such as Politique Africaine and organizations like the MRAP and the MAA were quick to denounce its racist undertones and implicit support of apartheid policies. In a response to a Le Monde article of January 1983 - where the film critic Jacques Siclier considered the movie amusing ${ }^{6}$ - Politique Africaine denounced the movie as a tool of apartheid propaganda, and firmly condemned Western societies for their positive reception to it:

"The Gods must be Crazy" constitute a convoluted justification of apartheid ideology: by masking the true fate done to these people [black South Africans], it comforts the theory of separation as the best means for cultural preservation and for the happiness of the "primitives" and highlights the validity of the Bantustans policy and their independence. ${ }^{7}$ At a moment where anti-apartheid movements seem to be acquiring a larger audience (in France, but not only) [...] the release of this movie and its success towards a particularly large audience skilfully contributes to illustrate the principal themes of Pretoria propaganda [own translation]. (Martin 1983)

The movie was also the subject of criticism at the Amiens Film Festival against Racism and for Friendship between Peoples held in November 1983, which led to the publication of a special issue of the journal L'Afrique Littéraire in 1986 entitled 'Le cinéma sud-africain est-il tombé sur la tête?", in reference to the French translation of the movie's title. Coordinated by Keyan Tomaselli, this special issue situated Jamie Uys's work within the broader framework of

\footnotetext{
${ }^{5}$ For more information on the capacity of race-based humour in upholding racial ideologies of white supremacy, see Pérez R. 2016. "Racist humor: then and now." Sociology Compass 10 (10): 928-938.

${ }^{6}$ Siclier, Jacques. 1983. "Les Dieux sont tombés sur la tête, de Jamie Uys à cause d'une bouteille vide". Le Monde.

${ }^{7}$ For more information, on the Bantustan system of apartheid, see the website South African History Online: http://www.sahistory.org.za/article/homelands.
} 
apartheid and anti-apartheid cultural production and aimed at informing the public on the situation in South Africa and the day-to-day lived experiences of black South Africans. Nevertheless, due to the strong party apparatus of the French anti-apartheid movement and its entrenchment in ideological factions, it omitted the chance to strongly denounce the movie and relegated cultural and symbolical action to particular fringes of the solidarity movement. In the 1980s, the cultural movement coalesced around the figure of Nelson Mandela, and call for his release and that of all political prisoners gave a new momentum to the transnational antiapartheid movement. However, this "Mandelafication" of the struggle on the international scene led to a certain erasure of the multiple histories constitutive of the South African liberation movement, and enabled the tenets of a movie such as The Gods must be Crazy to pass rather unnoticed in French society.

\section{Conclusion}

Therefore, this paper has highlighted the important role cultural and symbolic action played in raising awareness on the apartheid situation in South Africa. Though black South African exiles met with initial hostility at their arrival in France, the mobilization of artists and intellectuals for the support of their struggle led to the cementing of transnational and cross-cultural contacts. However, the overall positive reception in France of The Gods must be Crazy, that effectively channelled the ideals of apartheid under the guise of comedy, forces us to reconsider the impact of the French anti-apartheid movement in changing Western mentalities. Nevertheless, one can nuance the different readings and interpretations of the movie and its actual effect on Western perceptions of South Africa:

Quite simply, different people create their own mental texts about the film. Those aware of how the myth was made and who lean towards intense antiracist feelings have read their interpretations into Uys's films. [...] For those who have no expectation, and who may know nothing about the San and the devastating circumstances of their historical relations with encroaching societies, the film may establish inaccurate perceptions about the San, Afrikaners, whites, blacks, and others. (Tomaselli 2006, 194)

In July 1997, a conference was held by the Institute for Historical Research at the University of the Western Cape entitled "Khoisan identities and cultural heritage", which emphasized the emergence of an identity discourse that aims at upholding the legacy of the Khoi and the San. 
As a result, though The Gods must be Crazy offered a simplistic, ahistorical, and apolitical representation of San actors and an idealized image of South Africa, the study of its reception in France offers the opportunity for its (re)evaluation within the context of anti-apartheid mobilization and invites us to rethink our conceptualization of borders and boundaries in cultural, as well as racial terms.

\section{References}

Bregin, E. 2001. "Miscast: Bushmen in the twentieth century." Current Writing: Text and Reception in Southern Africa $13 \quad$ (1): 87-107. https://doi.org/10.1080/1013929X.2001.9678095

Corbey, R. 1993. “Ethnographic Showcases, 1870-1930.” Cultural Anthropology 8 (3): 338369. https://www.jstor.org/stable/656317

Davis, P. 1996. In darkest Hollywood: Exploring the jungles of cinema's South Africa. Ohio: Ohio University Press.

Fauvelle, F-X., F. Bon and K. Sadr. 2007. "L'Ailleurs et l'avant." L'Homme 184: 25-45. https://doi.org/10.4000/lhomme.21895

Gurney, C. 2000. “"A Great Cause': The Origins of the Anti-Apartheid Movement, June 1959March 1960." Journal of Southern African Studies 26 (1): 123-144. https://www.jstor.org/stable/2637553

Konieczna, A. 2017. “La France, l'Afrique du Sud et les solidarités transnationales : l'activité du premier mouvement anti-apartheid français (1960-1974).” In Les nouvelles formes de contestations, edited by E. Bell and J-M. Ruiz. Université de Savoie: Laboratoire Langages, Littératures, Sociétés, Études Transfrontalières et Internationales.

Martin, D. 1983. "Bloc-notes: Pour parler de l'Afrique du Sud." Politique Africaine, no. 12. http://www.politique-africaine.com/numeros/pdf/012114.pdf

MRAP. 1999. “L’Afrique du Sud aujourd'hui.” Différences 210: 1-12. 
Nicholls, B. 2008. "Apartheid cinema and indigenous image rights: the 'Bushman myth' in Jamie Uys's The gods must be crazy." Scrutiny2 13 (1): 20-32. http://dx.doi.org/10.1080/18125440802085647

Sharpley-Whiting, T. D. 1999. Black Venus: Sexualized Savages, Primal Fears and Primitive Narratives in French. Durham: Duke University Press.

Thomas, E. M. 1988 (1959). The Harmless People. Cape Town: David Philip.

Thörn, H. 2006. Anti-apartheid and the emergence of a global civil society, New York: Palgrave Macmillan.

Tomaselli, K. G. 1992. "Myth, Racism and Opportunism: Film and TV Representations of the San.” In Film as Ethnography, edited by P. J Crawford and D. Turton. Manchester: Manchester University Press.

Tomaselli, K. G. 2006. "Rereading the Gods must be Crazy Films." Visual Anthropology 19 (2): 171-200. http://dx.doi.org/10.1080/08949460600598711

Tomaselli, K. G. (ed.) and P. Davis. 1986. "Le cinéma sud-africain est-il tombé sur la tête ?" L'Afrique Littéraire 78: 1-128.

Uys, J. 1980. The Gods must be Crazy. 109 min. Mimosa Films.

\section{Archival material}

\section{Archives départementales de la Seine-Saint-Denis - Seine-Saint-Denis, France}

Archives de l'Association française d'amitié et de solidarité avec les peuples d'Afrique (AFASPA) 1940-1995.

67J 141. “Afrique du Sud". Rencontre Nationale Contre l'Apartheid. "Historique".

\section{Archives Nationales du Monde du Travail - Roubaix, France}

Mouvement Anti-Apartheid (1955-1992). 
2000-057-MAA-001. 1975. "La campagne anti-Outspan: Pour informer l'opinion publique français sur l'Afrique du Sud, l'apartheid et l'exploitation des travailleurs noirs".

\section{UWC-Robben Island Museum Mayibuye Archives - Cape Town, South Africa}

MCH 132. De Seynes, C. 1979. Notes sur l'APARTHEID mis en images et expliqué dans les écoles. Afrique du Sud Apartheid.

\section{Interviews}

John Kani (by Namara Burki, Johannesburg, 16 January 2018).

Horst Kleinschmidt (by Namara Burki, Cape Town, 01 February 2018).

\section{Acronyms}

AAA Artists Against Apartheid

AAM Anti-Apartheid Movement (UK)

AFASPA Association Française d'Amitié et de Solidarité avec les Peuples d'Afrique

ANC African National Congress

BCM Black Consciousness Movement

CAO Comité Anti-Outspan

COSATU Congress of South African Trade Unions

IDAF International Defence and Aid Fund

MAA Mouvement Anti-Apartheid (France)

MRAP Mouvement contre le Racisme et pour l'Amitié entre les Peuples

PAC Pan-Africanist Congress of Azania

PCF Parti Communiste Français

PS Parti Socialiste

SWAPO South West African People's Organisation

UDF United Democratic Front 